\title{
Evaluation of liver-type fatty acid binding protein (L-FABP) and interleukin 6 in children with renal cysts
}

\author{
Krzysztof Plesiński ${ }^{1, A-D}$, Piotr Adamczyk ${ }^{2, A, D, E}$, Elżbieta Świętochowska, ${ }^{3, C, E}$, Aurelia Morawiec-Knysak ${ }^{4, C, F}$, \\ Aleksandra Gliwińska ${ }^{4, B, E}$, Wojciech Korlacki ${ }^{5, B, E, F}$, Maria Szczepańska ${ }^{2, A, E, F}$ \\ ${ }^{1}$ Cardiological Outpatient Center "Medicor", Myszków, Poland \\ ${ }^{2}$ Department of Pediatrics, School of Medicine with the Division of Dentistry in Zabrze, Medical University of Silesia in Katowice, Poland \\ ${ }^{3}$ Chair and Department of Medical and Molecular Biology, School of Medicine with the Division of Dentistry in Zabrze, Medical University of Silesia in Katowice, Poland \\ ${ }^{4}$ Pediatric Nephrology Ward, Public Clinical Hospital No. 1 in Zabrze, Poland \\ ${ }^{5}$ Department of Children's Developmental Defects Surgery and Traumatology, School of Medicine with the Division of Dentistry in Zabrze, Medical University of Silesia \\ in Katowice, Poland
}

A - research concept and design; $\mathrm{B}$ - collection and/or assembly of data; $\mathrm{C}$ - data analysis and interpretation;

$D$ - writing the article; $E$ - critical revision of the article; $F$ - final approval of the article

\section{Address for correspondence \\ Maria Szczepańska \\ E-mail:mszczepanska@szpital.zabrze.pl}

\section{Funding sources}

Grant KNW-102/N/6/K from the Medical University

of Silesia in Katowice, Poland.

Conflict of interest

None declared

Received on March 26, 2019

Reviewed on May 29, 2019

Accepted on June 27, 2019

Published online on November 28, 2019

Cite as

Plesiński K, Adamczyk P, Świętochowska E, et al. Evaluation of liver-type fatty acid binding protein (L-FABP) and interleukin 6 in children with renal cysts. Adv Clin Exp Med. 2019;28(12):1675-1682. doi:10.17219/acem/110312

DOI

10.17219/acem/110312

Copyright

Copyright by Author(s)

This is an article distributed under the terms of the

Creative Commons Attribution 3.0 Unported (CC BY 3.0)

(https://creativecommons.org/licenses/by/3.0/)

\section{Abstract}

Background. Renal cysts, according to their etiology, can be divided into genetic and acquired cysts. This is of great importance in patients with cystic kidney disease with a possible poor prognosis to identify markers of early kidney damage.

Objectives. The objective of this study was to evaluate the concentration of serum and urine liver-type fatty acid binding protein (L-FABP) and interleukin 6 (IL-6) in children with kidney cysts.

Material and methods. The study was conducted on a group of 39 children with kidney cysts including 20 subjects with autosomal dominant polycystic kidney disease (ADPKD).

Results. Serum and urine L-FABP concentration in children with renal cysts was significantly higher compared to the controls, regardless of the underlying type of cystic degeneration, number of cysts and gender. Also, serum and urinary IlL-6 concentration was significantly higher than in the control group. There was a significant negative correlation between serum L-FABP concentration and standard deviation score (SDS) for diastolic blood pressure (DBP). A significant negative correlation was found between serum IL-6 concentration and systolic blood pressure (SBP), DBP and mean arterial pressure (MAP) values as well as SDS for SBP and DBP. In addition, a significant positive correlation was found between urinary lL-6 concentration and estimated glomerular filtration rate (eGFR).

Conclusions. Higher concentration of L-FABP in serum and urine in children with kidney cysts indicates the early damage to the renal parenchyma, detectable before the onset of hypertension and other organ damage. Significantly higher serum and urinary IL-6 levels in children with cystic kidney disease compared to healthy children may suggest the role of this cytokine in chronic kidney disease development.

Key words: children, interleukin 6, autosomal dominant polycystic kidney disease, liver-type fatty acid binding protein, kidney cysts 


\section{Introduction}

The kidney cyst is defined as a space filled with fluid of non-uniform size, which arises in various locations as a result of widening and changing of the structure of renal tubules. The most common are simple kidney cysts that can appear in kidneys not affected with any defined disease, and their number often increases with age. They usually do not cause clinical symptoms and, therefore, are detected accidentally during an ultrasound examination. In 1964, Osathanondh et al. classified renal cysts into 4 categories. Type I was identified with autosomal recessive polycystic kidney disease (ARPKD), type II was described as polycystic renal dysplasia, type III referred to autosomal dominant polycystic kidney disease (ADPKD), while type IV included pathologies associated with impaired urine outflow and the presence of hydronephrosis. ${ }^{1}$

Currently, the classification of diseases related to the presence of cysts in the kidneys is of an etiological basis and includes, apart from the family history, also the clinical picture, the location and morphology of the cysts as well as the presence of extrarenal symptoms. ${ }^{2}$ Genetically caused cystic kidney diseases were systematized according to a new classification developed by Kim et al. ${ }^{2}$ Of these, ADPKD is the most common. ${ }^{3-6}$ Diagnosis of ADPKD due to the typical symptoms, initially before confirmation by genetic testing, is based on family history and imaging. ${ }^{6-8}$ For the diagnosis of ADPKD, the ultrasound criteria according to Ravine are currently used. ${ }^{6}$ The ADPKD is the most common genetically determined cause of end-stage renal failure in adults. ${ }^{3,5,9}$ The reason for the development of ADPKD in 80-85\% of cases is the mutation of the PKD1 gene, which encodes the polycystine-1 protein, while in the remaining $15-20 \%$ of patients it is the PKD2 gene encoding polycystin- $2 .{ }^{10}$ Incorrectly encoded proteins that arise as a result of mutations lead to the growth and proliferation of kidney tubules cells with the formation of cysts, then to their enlargement and secretion and collection of fluid inside them. ${ }^{11}$ In patients with ADPKD, hypertension occurs much earlier than in the general population and often in childhood, which leads to left ventricular hypertrophy, followed by diastolic and later on systolic heart dysfunction. ${ }^{12,15,16}$ In about $30-50 \%$ of patients with ADPKD, hematuria may occur. In children proteinuria or albuminuria may be present as well. In the course of ADPKD, concomitant cysts in the liver and other organs could be present as well as intracerebral aneurysms, which carry the risk of subarachnoid hemorrhage. ${ }^{13,17}$

Fatty acid binding proteins (FABPs) are low molecular weight cytoplasmic proteins of $14-15 \mathrm{kDa}$. The physiological role of these proteins is to bind free long chain fatty acids and transfer them to intracellular sites of utilization or storage in the cytoplasmic reticulum and cytoplasm. ${ }^{18,19}$

We currently know 9 types of these proteins with their names derived from the organ or tissue in which they were identified for the first time. Liver fatty acid binding protein (L-FABP) was first detected in hepatocytes, but it is also synthesized in the small and large intestine, lungs and kidneys. ${ }^{19-21}$ It binds fatty acids and transports them to mitochondria and peroxisomes, where they are metabolized by beta-oxidation and in that manner provide energy to the epithelial cells. ${ }^{19,21,22}$ It has a high affinity to fatty acid peroxidation products, participating in the urinary excretion process, which makes L-FABP an endogenous antioxidant. ${ }^{19}$ In recent years, attention has been paid to the prognostic value of L-FABP in kidney disease. Liver fatty acid binding proteins circulating in the blood are filtered in the glomeruli and then reabsorbed at the proximal renal tubules, which explains the increase in their concentration in the urine in the case of damage to the proximal tubules. ${ }^{19,22,23}$

Interleukin 6 (IL-6) is one of the main factors regulating defense mechanisms of the body. Formerly, IL- 6 was determined as factor 2 stimulating B lymphocytes, $\beta 2$ interferon or the growth and differentiation factor of $\mathrm{T}$ cytotoxic lymphocytes. It is secreted primarily by macrophages and monocytes, but also by endothelial cells, fibroblasts, chondrocytes, and $\mathrm{T}$ and B lymphocytes. ${ }^{24}$ The most important role of IL- 6 is its participation in the immune response and inflammatory processes by stimulating the differentiation of B lymphocytes into plasma cells, production of acute phase proteins and activation of T lymphocytes. ${ }^{24-26}$ Interleukin 6 also participates in hematopoiesis by stimulating hematopoietic stem cells and inducing differentiation of megakaryocytes into platelets. Interleukin 6 produced in excess leads to the development of chronic inflammatory reaction, conducive to the development of autoreactive immune response, leading to the destruction of tissues and organs. Elevated levels of IL- 6 have been confirmed in multiple myeloma, chronic lymphocytic leukemia, Alzheimer's disease, systemic lupus erythematosus, rheumatoid arthritis, Castelman's disease, connective tissue diseases, as well as hypertension. ${ }^{25-27}$ Chronic inflammatory process, mediated by IL- 6 among others, contributes to the increase in blood pressure (BP). Interleukin 6 also affects the growth and development of hypertension by stimulating the sympathetic nervous system and controlling the expression of angiotensinogen, resulting in an increase in angiotensin II. In addition to the direct effect on BP, the increase in IL- 6 concentration is associated with obesity, coronary heart disease and diabetes, the last of which also contributes to the development of hypertension and enhances the progression of chronic kidney disease (CKD). ${ }^{28}$

Recently, new markers have been proposed for the diagnosis of early kidney damage in the course of cystic kidney disease. This could help to identify children whose disease progresses faster, with a higher risk of developing organ complications and end-stage renal failure in adolescence or young adulthood.

The hypothesis of our work is the statement that such markers may include the following: protein binding fatty 
acids of liver origin (L-FABP) and IL-6. The aim of the study was to assess the usefulness of determining protein-FABP and IL- 6 concentrations in serum and urine in children with kidney cysts of various etiologies and their relationship to the underlying cystic kidney disease, the number of cysts found, gender, and hypertension.

\section{Material and methods}

The study group consisted of 39 children and adolescents (23 girls and 16 boys) between 1.9 and 20 years of age (mean age $10.9 \pm 5.0$ years) with renal cysts. In all children, we confirmed the presence of cysts in the renal parenchyma on the basis of an ultrasound examination. After conducting family history and evaluation of ultrasounds according to Ravine's criteria, ${ }^{7}$ we identified in the study group the following subgroups of children: with ADPKD (20 children - 51\%) and without diagnosis of this disease - non-ADPKD (19 children - 49\%). Analyzing the number of cysts found on the basis of ultrasound, we identified children with single cysts - less than 10 cysts (29 children - 74\%) and multiple cysts (10 children - 26\%) in the study group. Most of the children in the study group did not take any medications. Only 4 children with hypertension were successfully treated with antihypertensive drugs. In 15 children from the study group, we showed a positive family history of ADPKD. Body mass, height, BP measurement and routine biochemical tests were performed in the study group - assessment of sodium, potassium, creatinine, urea, and uric acid serum concentration. Blood pressure measurements were made using an oscillometric pressure device, with a cuff placed on the arm. The tests were performed 3 times, in the sitting position, after 5-10 min rest, according to the recommended standards, and the average value of the measurements was calculated. The size of the cuff of the oscillometric pressure device was appropriately matched to the circumference and length of the child's arm in accordance with the recommended measurement principles. Hypertension was diagnosed if the mean of measured systolic blood pressure (SBP) or diastolic blood pressure (DBP) was equal to or exceeding 95.cc for age, sex and height according to the Polish pediatric population. ${ }^{29-31}$ Estimated glomerular filtration rate (eGFR) was calculated using the Schwartz formula $\left[\mathrm{mL} / \mathrm{min} / 1.73 \mathrm{~m}^{2}\right] .^{14}$

The control group included 20 healthy children (10 girls and 10 boys). These were ambulatory patients diagnosed due to bedwetting or qualified for "one-day" surgical procedures, who additionally agreed to participate in the study. All subjects were in good clinical condition and had no symptoms of acute infection.

We obtained the consent of the Bioethics Committee of the Silesian Medical University in Katowice, Poland (resolution No. KNW/0022/KB1/21/15). Prior to the examination, written consent was obtained for participation in the project from parents or legal guardians and from children over 16 years of age.

\section{Laboratory tests}

Blood samples (3-5 mL) for laboratory tests were collected in the morning (8.00-9.00 am) into Eppendorf tubes, during routine tests related to periodic outpatient supervision. After centrifugation at $1,000 \times \mathrm{g}$ for $15 \mathrm{~min}$ at $4^{\circ} \mathrm{C}$, the serum was stored at $-20^{\circ} \mathrm{C}$ until laboratory tests were performed. Urine samples $(50-100 \mathrm{~mL})$ were also collected in the morning and stored at $-20^{\circ} \mathrm{C}$ until testing. The standard BioVendor kit (BioVendor, Brno, Czech Republic) was used to determine the concentration of L-FABP in serum and urine according to the manufacturer's protocol (sensitivity $0.08 \mathrm{ng} / \mathrm{mL}$ ). The concentration of IL-6 in serum and urine was tested with enzyme-linked immunosorbent assay (ELISA) using a standard kit from Diaclone (Besançon, France) according to the manufacturer's protocol (sensitivity $0.81 \mathrm{pg} / \mathrm{mL}$ ).

\section{Statistical analysis}

The Excel spreadsheet from Microsoft Office package v. 16.0 (Microsoft Corp., Armonk, USA) was used to prepare the database. The calculations were performed using STATISTICA v. 12.0 software (StatSoft Inc., Tulsa, USA). In statistical calculations, the level of significance was $\mathrm{p}<0.05$. As parameters of descriptive statistics, the following were assumed: arithmetic mean, median, minimum and maximum value, lower and upper quartiles, and standard deviation (SD). For all parameters, their distribution was checked for compatibility with the normal distribution using the Shapiro-Wilk test. We tested the homogeneity of variance using Levene's test. For comparison of variables with a normal distribution, parametric tests with a separate variance assessment were used. For comparative analysis of variables with distribution deviated from the normal distribution, nonparametric Mann-Whitney U test was used. We performed the correlation analysis using the Pearson's test or Spearman's rank correlation test - according to the distribution of the variables studied.

\section{Results}

Table 1 presents the characteristics of the entire study group of children with renal cysts and the derived subgroups (ADPKD and non-ADPKD, number of cysts and gender) and the control group. The average age of children and anthropometric parameters did not differ in comparison with the group with renal cysts and control group. We showed significantly higher values of SBP, DBP and mean arterial pressure (MAP), as well as SBP and DBP 
Table 1. Characteristics of examined children with renal cysts and controls

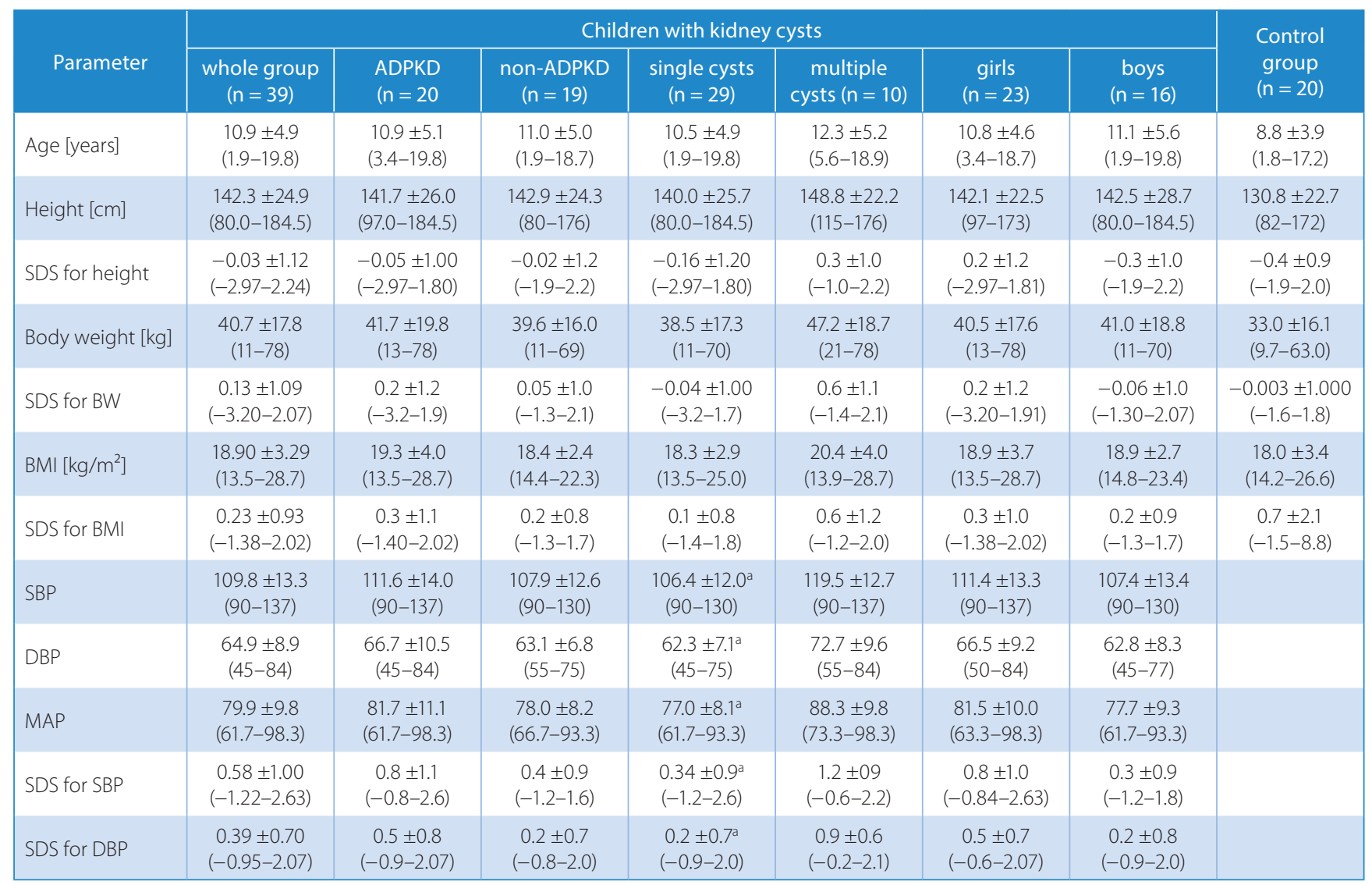

Data is presented as: mean \pm standard deviation (SD) (minimum-maximum); ${ }^{a} \mathrm{p}<0.05$ children with single cysts vs children with multiple cysts; BW SDS - SDS body weight, BMI - body mass index; SBP - systolic blood pressure, DBP - diastolic blood pressure, MAP - mean arterial pressure; ADPKD - autosomal dominant polycystic kidney disease.

Table 2. Laboratory tests and eGFR value in children with renal cysts

\begin{tabular}{|l|c|c|c|c|c|c|c|}
\multicolumn{1}{|c|}{ Parameter } & $\begin{array}{c}\text { Whole group } \\
(\mathrm{n}=39)\end{array}$ & $\begin{array}{c}\text { ADPKD } \\
(\mathrm{n}=20)\end{array}$ & $\begin{array}{c}\text { Non-ADPKD } \\
(\mathrm{n}=19)\end{array}$ & $\begin{array}{c}\text { Single cysts } \\
(\mathrm{n}=29)\end{array}$ & $\begin{array}{c}\text { Multiple cysts } \\
(\mathrm{n}=10)\end{array}$ \\
\hline $\mathrm{Na}$ & $140.1 \pm 2.2$ & $140.0 \pm 2.5$ & $140.2 \pm 1.7$ & $140.2 \pm 1.8$ & $139.9 \pm 3.1$ & $140.3 \pm 1.7$ \\
$(\mathbf{n}=23)$
\end{tabular}

Data is presented as: mean \pm standard deviation (SD) (minimum-maximum). For all comparisons p $>0.05$. eGFR - estimated glomerular filtration rate; ADPKD - autosomal dominant polycystic kidney disease.

SDS in a subgroup of children with multiple cysts compared to subgroups of subjects with single cysts. The results of laboratory tests in the study group and in separate subgroups are presented in Table 2.

The mean values of basic laboratory tests in the group of ADPKD and non-ADPKD children as well as single and multiple cysts did not differ significantly. The mean value of eGFR in the study group was $119.8 \pm 32.7 \mathrm{~mL} / \mathrm{min} / 1.73 \mathrm{~m}^{2}$; in 5 children in the group with cystic kidney disease the value of eGFR was reduced. Moreover, in 4 children in the study group, we diagnosed hypertension (all of them belonged to the ADPKD subgroup).

The concentrations of the tested markers (L-FABP, IL-6) in serum and urine in children from the study and control groups are presented in Table 3. The concentration of L-FABP and IL-6 in serum and urine was significantly higher in children with cystic kidney disease compared to the healthy children. In contrast, serum and urinary 
Table 3. Concentration of the examined parameters in serum and in urine in children with kidney cysts (divided into subgroups) and in controls

\begin{tabular}{|c|c|c|c|c|c|c|c|c|}
\hline \multirow[b]{2}{*}{ Parameter } & \multicolumn{7}{|c|}{ Children with kidney cysts } & \multirow{2}{*}{$\begin{array}{l}\text { Control group } \\
\qquad(n=20)\end{array}$} \\
\hline & $\begin{array}{l}\text { whole group } \\
\qquad(\mathrm{n}=39)\end{array}$ & $\begin{array}{l}\text { ADPKD } \\
(n=20)\end{array}$ & $\begin{array}{c}\text { non-ADPKD } \\
(n=19)\end{array}$ & $\begin{array}{c}\text { girls } \\
(n=23)\end{array}$ & $\begin{array}{c}\text { boys } \\
(n=16)\end{array}$ & $\begin{array}{l}\text { single cysts } \\
\quad(n=29)\end{array}$ & $\begin{array}{c}\text { multiple } \\
\text { cysts }(n=10)\end{array}$ & \\
\hline $\begin{array}{l}\text { L-FABP (S) } \\
{[\mathrm{ng} / \mathrm{mL}]}\end{array}$ & $\begin{array}{c}70.2 \pm 17.1^{*} \\
(44.3-100.1)\end{array}$ & $\begin{array}{c}68.5 \pm 17.3 \\
(44.3-96.5)\end{array}$ & $\begin{array}{c}71.9 \pm 17.3 \\
(46.8-100.0)\end{array}$ & $\begin{array}{c}69,0 \pm 15.8 \\
(45.8-95.7)\end{array}$ & $\begin{array}{c}71.9 \pm 19.3 \\
(44.3-100.0)\end{array}$ & $\begin{array}{c}72.9 \pm 17.3 \\
(44.3-100.0)\end{array}$ & $\begin{array}{c}62.1 \pm 14.7 \\
(45.8-96.5)\end{array}$ & $\begin{array}{c}2.6 \pm 0.77 \\
(1.1-3.7)\end{array}$ \\
\hline $\begin{array}{l}\text { L-FABP }(U) \\
{[n g / m L]}\end{array}$ & $\begin{array}{l}12.2 \pm 4.1^{*} \\
(4.7-19.6)\end{array}$ & $\begin{array}{l}11.0 \pm 3.3 \\
(4.7-16.4)\end{array}$ & $\begin{array}{l}13.5 \pm 4.5 \\
(5.8-19.5)\end{array}$ & $\begin{array}{c}11.9 \pm 4.1 \\
(5.8-19.6)\end{array}$ & $\begin{array}{l}12.6 \pm 4.2 \\
(4.7-18.8)\end{array}$ & $\begin{array}{l}13.3 \pm 4.0 \\
(4.7-19.6)\end{array}$ & $\begin{array}{c}9.1 \pm 2.5 \\
(5.9-14.6)\end{array}$ & $\begin{array}{c}2.76 \pm 0.6 \\
(1.86-4.10)\end{array}$ \\
\hline L-FABP (S)/BMI & $\begin{array}{l}3.8 \pm 1.1^{*} \\
(2.1-6.7)\end{array}$ & $\begin{array}{c}3.63 \pm 0.90 \\
(2.1-5.8)\end{array}$ & $\begin{array}{l}4.0 \pm 1.3 \\
(2.5-6.7)\end{array}$ & $\begin{array}{l}3.8 \pm 1.1 \\
(2.1-6.5)\end{array}$ & $\begin{array}{l}3.9 \pm 1.2 \\
(2.6-6.7)\end{array}$ & $\begin{array}{l}4.0 \pm 1.2 \\
(2.5-6.7)\end{array}$ & $\begin{array}{l}3.1 \pm 0.8 \\
(2.1-4.8)\end{array}$ & $\begin{array}{c}0.15 \pm 0.06 \\
(0.06-0.26)\end{array}$ \\
\hline L-FABP/creat (U) & $\begin{array}{c}64.7 \pm 24.7 \\
(14.6-123.1)\end{array}$ & $\begin{array}{l}59.8 \pm 22.4 \\
(14.6-92.1)\end{array}$ & $\begin{array}{c}69.8 \pm 26.5 \\
(23.9-123.0)\end{array}$ & $\begin{array}{c}64.3 \pm 23.3 \\
(16.8-108.7)\end{array}$ & $\begin{array}{c}65.2 \pm 27.3 \\
(14.6-123.0)\end{array}$ & $\begin{array}{l}68.3 \pm 24.2 \\
(14.6-123)\end{array}$ & $\begin{array}{l}54.1 \pm 24.1 \\
(16.8-92.1)\end{array}$ & \\
\hline $\begin{array}{l}\text { IL-6 (S) } \\
{[\mathrm{ng} / \mathrm{mL}]}\end{array}$ & $\begin{array}{l}23.4 \pm 4.6^{*} \\
(11.3-33.7)\end{array}$ & $\begin{array}{c}23.3 \pm 5.3 \\
(11.3-31.8)\end{array}$ & $\begin{array}{c}23.5 \pm 3.9 \\
(18.8-33.7)\end{array}$ & $\begin{array}{c}22.0 \pm 4.0 \\
(11.3-30.2)\end{array}$ & $\begin{array}{c}25.4 \pm 4.8 \\
(17.3-33.7)\end{array}$ & $\begin{array}{c}23.9 \pm 4.3 \\
(17.9-33.7)\end{array}$ & $\begin{array}{c}22.1 \pm 5.5 \\
(11.3-30.2)\end{array}$ & $\begin{array}{c}7.4 \pm 1.4 \\
(4.8-9.6)\end{array}$ \\
\hline $\begin{array}{l}\text { IL-6 (U) } \\
{[\mathrm{ng} / \mathrm{mL}]}\end{array}$ & $\begin{array}{c}90.3 \pm 15.7^{*} \\
(63.8-135.7)\end{array}$ & $\begin{array}{c}93.5 \pm 18.4 \\
(63.8-135.7)\end{array}$ & $\begin{array}{c}86.9 \pm 11.8 \\
(69.9-114.8)\end{array}$ & $\begin{array}{c}85.6 \pm 12.4 \\
(63.8-116.1)\end{array}$ & $\begin{array}{c}97.0 \pm 17.9 \\
(69.9-135.7)\end{array}$ & $\begin{array}{c}90.0 \pm 15.4 \\
(63.8-135.7)\end{array}$ & $\begin{array}{c}91.0 \pm 17.2 \\
(69.8-123.0)\end{array}$ & $\begin{array}{c}36.9 \pm 12.3 \\
(18.6-55.7)\end{array}$ \\
\hline IL-6 (S)/BMI & $\begin{array}{l}1.3 \pm 0.4^{*} \\
(0.7-2.2)\end{array}$ & $\begin{array}{l}1.3 \pm 0.4 \\
(0.7-2.2)\end{array}$ & $\begin{array}{l}1.3 \pm 0.3 \\
(0.8-2.0)\end{array}$ & $\begin{array}{l}1.2 \pm 0.4 \\
(0.7-2.2)\end{array}$ & $\begin{array}{l}1.4 \pm 0.4 \\
(0.8-2.0)\end{array}$ & $\begin{array}{l}1.3 \pm 0.3 \\
(0.8-2.0)\end{array}$ & $\begin{array}{l}1.1 \pm 0.4 \\
(0.7-2.2)\end{array}$ & $\begin{array}{l}0.42 \pm 0.1 \\
(0.3-0.6)\end{array}$ \\
\hline IL-6/creat (U) & $\begin{array}{c}477.9 \pm 157.6 \\
(246.0-997.7)\end{array}$ & $\begin{array}{l}504.5 \pm 186.1 \\
(246.0-997.7)\end{array}$ & $\begin{array}{l}450 \pm 119.4 \\
(325-774)\end{array}$ & $\begin{array}{c}460.7 \pm 112.6 \\
(246.6-773.9)\end{array}$ & $\begin{array}{c}502.7 \pm 207.8 \\
(300.0-997.7)\end{array}$ & $\begin{array}{c}460.6 \pm 142.1 \\
(300-932)\end{array}$ & $\begin{array}{c}528.1 \pm 195.5 \\
(246.6-997.7)\end{array}$ & \\
\hline
\end{tabular}

Data is presented as: mean \pm standard deviation (SD) (minimum-maximum); $p^{*}, p<0.05$ the whole group of children with kidney cystic disease vs control group; L-FABP - liver fatty acid binding protein; IL-6 - interleukin 6; S - serum; U - urine; ADPKD - autosomal dominant polycystic kidney disease; $\mathrm{BMI}$ - body mass index.

Table 4. Analysis of correlation between blood pressure, eGFR values and the tested markers concentration

\begin{tabular}{|c|c|}
\hline Parameter & Children with kidney cysts - whole group \\
\hline $\mathrm{SBP}[\mathrm{mm} \mathrm{Hg}]$ & serum IL-6r $r=-0.485, p<0.01$ \\
\hline $\mathrm{DBP}[\mathrm{mm} \mathrm{Hg}]$ & serum IL-6r $r=-0.425, p<0.01$ \\
\hline $\mathrm{MAP}[\mathrm{mm} \mathrm{Hg}]$ & serum IL-6 $r=-0.477, p<0.01$ \\
\hline SBP SDS & $\begin{array}{c}\text { serum IL- } 6 r=-0.565, p<0.0001 \\
\text { urine IL-6r } r=-0.452, p<0.01\end{array}$ \\
\hline DBP SDS & $\begin{array}{c}\text { serum L-FABP } r=-0.356, p<0.05 \\
\text { serum IL-6 } r=-0.417, p<0.01 \\
\text { urine IL-6 } r=-0.379, p<0.05\end{array}$ \\
\hline $\mathrm{eGFR}\left[\mathrm{mL} / \mathrm{min} / 1.73 \mathrm{~m}^{2}\right]$ & urine IL-6r $r=0.400, p<0.05$ \\
\hline
\end{tabular}

SBP - systolic blood pressure; DBP - diastolic blood pressure;

MAP - mean arterial pressure; L-FABP - liver fatty acid binding protein; IL-6 - interleukin 6; eGFR - estimated glomerular filtration rate.

concentrations of L-FABP and IL-6 in individual subgroups of children with renal cysts were comparable.

When analyzing the correlation of L-FABP and IL-6 concentrations in both serum and urine, and anthropometric measurements, we did not show any significant relationships in the whole group of children with renal cysts.

We showed a significant negative correlation between serum L-FABP concentration and SDS for DBP in the whole study group (Table 4). In children with cystic kidney disease, we observed a significant negative correlation between IL-6 serum concentration and absolute values and SDS for SBP, DBP and MAP. There was also a significant negative correlation between urinary IL- 6 concentration and SDS for SBP and DBP. In addition, a significant positive correlation was found between urinary IL- 6 concentration and eGFR. Similar correlations were observed in the study group by analyzing the correlation of IL- 6 with body mass index (BMI) (data not shown). However, in the whole group with cystic renal changes, we found a negative correlation between L-FABP/BMI ratio and SBP $(\mathrm{r}=-0.460$, $\mathrm{p}<0.01)$, $\operatorname{DBP}(\mathrm{r}=-0.378, \mathrm{p}<0.05), \operatorname{MAP}(\mathrm{r}=-437, \mathrm{p}<0.01)$, SDS for $\operatorname{SBP}(\mathrm{r}=-0.373, \mathrm{p}<0.05)$, and eGFR $(\mathrm{r}=-0.398, \mathrm{p}<0.05)$, and positive correlation between $\mathrm{L}-\mathrm{FABP} / \mathrm{BMI}$ ratio and serum urea concentration $(\mathrm{r}=0.343, \mathrm{p}<0.05)$. We also analyzed correlations occurring in subgroups, divided into ADPKD and non-ADPKD (Table 5). We have demonstrated in children with ADPKD a positive correlation between serum L-FABP concentration and serum creatinine concentration and serum uric acid concentration. In addition, in children with ADPKD, we found a positive correlation between the excretion of L-FABP in the urine and the concentration of serum uric acid. In children from the non-ADPKD subgroup, we found a negative correlation between serum L-FABP concentration, SDS for BMI and SDS for DBP and DBP absolute values. In the whole study group with renal cysts, we found a negative correlation between L-FABP/BMI ratio and SBP $(r=-0.460$, $\mathrm{p}<0.005)$, DBP $(\mathrm{r}=-0.378, \mathrm{p}<0.02)$, MAP $(\mathrm{r}=-0.437$, $\mathrm{p}<0.005)$, SDS for SBP $(\mathrm{r}=-0.377, \mathrm{p}<0.02)$, and eGFR $(\mathrm{r}=-0.398, \mathrm{p}<0.02)$, and a positive correlation between L-FABP/BMI ratio and serum urea $(r=0.343, \mathrm{p}<0.05)$. However, after normalizing the concentration of L-FABP in urine to the concentration of creatinine, we did not observe the above relationships.

When analyzing the correlation of serum and urine IL- 6 concentrations with the results of anthropometric measurements and the IL-6/BMI ratio with BP values, we demonstrated a similar relationship in ADPKD children as in the whole study group, and a significant positive 
Table 5. Evaluation of the correlation between the tested markers and biochemical parameters and blood pressure values

\begin{tabular}{|c|c|c|c|c|c|c|c|c|}
\hline \multirow{3}{*}{ Parameter } & \multicolumn{8}{|c|}{ Children with kidney cysts } \\
\hline & \multicolumn{2}{|c|}{ L-FABP (S) } & \multicolumn{2}{|c|}{ L-FABP (U) } & \multicolumn{2}{|c|}{ IL-6 (S) } & \multicolumn{2}{|c|}{ IL-6 (U) } \\
\hline & $\overline{A D P K D}$ & non-ADPKD & ADPKD & non-ADPKD & ADPKD & non-ADPKD & ADPKD & non-ADPKD \\
\hline SBP & $\begin{array}{l}r=-0.038 \\
p=0.874\end{array}$ & $\begin{array}{l}r=-0.254 \\
p=0.294\end{array}$ & $\begin{array}{c}r=-0.293 \\
p=0.210\end{array}$ & $\begin{array}{l}r=-0.092 \\
p=0.709\end{array}$ & $\begin{array}{c}r=-0.485 \\
p<0.05\end{array}$ & $\begin{array}{c}r=-0.497 \\
p<0.05\end{array}$ & $\begin{array}{l}r=-0.245 \\
p=0.297\end{array}$ & $\begin{array}{c}r=-0.298 \\
p=0.216\end{array}$ \\
\hline DBP & $\begin{array}{l}r=0.021 \\
p=0.930\end{array}$ & $\begin{array}{c}r=-0.493 \\
p<0.05\end{array}$ & $\begin{array}{l}r=-0.186 \\
p=0.433\end{array}$ & $\begin{array}{c}r=-0.300 \\
p=0.212\end{array}$ & $\begin{array}{c}r=-0.469 \\
p<0.05\end{array}$ & $\begin{array}{c}r=-0.350 \\
p=0.142\end{array}$ & $\begin{array}{c}r=-0.228 \\
p=0.333\end{array}$ & $\begin{array}{c}r=-0.392 \\
p=0.097\end{array}$ \\
\hline MAP & $\begin{array}{c}r=-0.003 \\
p=0.991\end{array}$ & $\begin{array}{c}r=-0.404 \\
p=0.086\end{array}$ & $\begin{array}{c}r=-0.240 \\
p=0.307\end{array}$ & $\begin{array}{l}r=-0.213 \\
p=0.381\end{array}$ & $\begin{array}{c}r=-0.500 \\
p<0.05\end{array}$ & $\begin{array}{l}r=-0.450 \\
p=0.053\end{array}$ & $\begin{array}{l}r=-0.247 \\
p=0.293\end{array}$ & $\begin{array}{c}r=-0.370 \\
p=0.119\end{array}$ \\
\hline SDS for SBP & $\begin{array}{l}r=-0.206 \\
p=0.384\end{array}$ & $\begin{array}{l}r=-0.393 \\
p=0.096\end{array}$ & $\begin{array}{l}r=-0.221 \\
p=0.349\end{array}$ & $\begin{array}{l}r=-0.128 \\
p=0.600\end{array}$ & $\begin{array}{c}r=-0.556 \\
p<0.05\end{array}$ & $\begin{array}{c}r=-0.603 \\
p<0.01\end{array}$ & $\begin{array}{c}r=-0.572 \\
p<0.01\end{array}$ & $\begin{array}{l}r=-0.417 \\
p=0.076\end{array}$ \\
\hline SDS for DBP & $\begin{array}{l}r=-0.167 \\
p=0.481\end{array}$ & $\begin{array}{c}r=-0.570 \\
p<0.05\end{array}$ & $\begin{array}{l}r=-0.158 \\
p=0.505\end{array}$ & $\begin{array}{l}r=-0.316 \\
p=0.187\end{array}$ & $\begin{aligned} r & =-0.505 \\
p & <0.05\end{aligned}$ & $\begin{array}{l}r=-0.286 \\
p=0.235\end{array}$ & $\begin{array}{c}r=-0.453 \\
p<0.05\end{array}$ & $\begin{array}{l}r=-0.445 \\
p=0.056\end{array}$ \\
\hline $\begin{array}{l}\text { Creatinine } \\
\text { [umol/L] }\end{array}$ & $\begin{array}{l}r=0.497 \\
p<0.05\end{array}$ & $\begin{array}{l}r=-0.131 \\
p=0.592\end{array}$ & $\begin{array}{l}r=0.237 \\
p=0.314\end{array}$ & $\begin{array}{l}r=0.019 \\
p=0.939\end{array}$ & $\begin{array}{c}r=-0.053 \\
p=0.824\end{array}$ & $\begin{array}{c}r=-0.324 \\
p=0.176\end{array}$ & $\begin{array}{l}r=0.047 \\
p=0.844\end{array}$ & $\begin{array}{c}r=-0.367 \\
p=0.122\end{array}$ \\
\hline $\begin{array}{l}\text { Urea } \\
\text { [umol/L] }\end{array}$ & $\begin{array}{l}r=-0.088 \\
p=0.712\end{array}$ & $\begin{array}{l}r=0.340 \\
p=0.154\end{array}$ & $\begin{array}{l}r=0.022 \\
p=0.925\end{array}$ & $\begin{array}{l}r=0.377 \\
p=0.112\end{array}$ & $\begin{array}{l}r=0.259 \\
p=0.270\end{array}$ & $\begin{array}{l}r=0.300 \\
p=0.212\end{array}$ & $\begin{array}{l}r=-0.222 \\
p=0.346\end{array}$ & $\begin{array}{l}r=0.132 \\
p=0.589\end{array}$ \\
\hline $\begin{array}{l}\text { Uric acid } \\
{[\mathrm{mmol} / \mathrm{L}]}\end{array}$ & $\begin{array}{l}r=0.572 \\
p<0.01\end{array}$ & $\begin{array}{l}r=-0.120 \\
p=0.624\end{array}$ & $\begin{array}{l}r=0.586 \\
p<0.01\end{array}$ & $\begin{array}{l}r=0.086 \\
p=0.727\end{array}$ & $\begin{array}{l}r=0.028 \\
p=0.907\end{array}$ & $\begin{array}{l}r=0.203 \\
p=0.403\end{array}$ & $\begin{array}{l}r=0.084 \\
p=0.725\end{array}$ & $\begin{array}{l}r=0.152 \\
p=0.535\end{array}$ \\
\hline $\begin{array}{l}\mathrm{Na} \\
{[\mathrm{mmol} / \mathrm{L}]}\end{array}$ & $\begin{array}{l}r=-0.163 \\
p=0.493\end{array}$ & $\begin{array}{l}r=0.147 \\
p=0.548\end{array}$ & $\begin{array}{c}r=-0.331 \\
p=0.154\end{array}$ & $\begin{array}{l}r=0.376 \\
p=0.112\end{array}$ & $\begin{array}{l}r=0.124 \\
p=0.602\end{array}$ & $\begin{array}{l}r=-0.020 \\
p=0.934\end{array}$ & $\begin{array}{l}r=-0.041 \\
p=0.865\end{array}$ & $\begin{array}{l}r=-0.243 \\
p=0.315\end{array}$ \\
\hline $\begin{array}{l}\mathrm{K} \\
{[\mathrm{mmol} / \mathrm{L}]}\end{array}$ & $\begin{array}{l}r=-0.100 \\
p=0.676\end{array}$ & $\begin{array}{l}r=0.431 \\
p=0.065\end{array}$ & $\begin{array}{c}r=-0.004 \\
p=0.986\end{array}$ & $\begin{array}{l}r=0.435 \\
p=0.063\end{array}$ & $\begin{array}{l}r=0.457 \\
p<0.05\end{array}$ & $\begin{array}{l}r=0.025 \\
p=0.920\end{array}$ & $\begin{array}{l}r=0.078 \\
p=0.744\end{array}$ & $\begin{array}{l}r=0.024 \\
p=0.923\end{array}$ \\
\hline $\begin{array}{l}\text { eGFR } \\
{\left[\mathrm{mL} / \mathrm{min} / 1.73 \mathrm{~m}^{2}\right]}\end{array}$ & $\begin{array}{l}r=-0.060 \\
p=0.802\end{array}$ & $\begin{array}{l}r=0.047 \\
p=0.846\end{array}$ & $\begin{array}{l}r=-0.284 \\
p=0.224\end{array}$ & $\begin{array}{l}r=-0.177 \\
p=0.469\end{array}$ & $\begin{array}{l}r=0.174 \\
p=0.463\end{array}$ & $\begin{array}{l}r=0.240 \\
p=0.321\end{array}$ & $\begin{array}{l}r=0.404 \\
p=0.077\end{array}$ & $\begin{array}{l}r=0.398 \\
p=0.091\end{array}$ \\
\hline
\end{tabular}

SBP - systolic blood pressure; DBP - diastolic blood pressure; MAP - mean arterial pressure; L-FABP - liver fatty acid binding protein; IL-6 - interleukin 6; $S$ - serum; U - urine; eGFR - estimated glomerular filtration rate; ADPKD - autosomal dominant polycystic kidney disease.

correlation between serum IL-6 concentration and serum potassium concentration. Also in children with ADPKD, we found a negative correlation between urinary IL-6 excretion and SDS for SBP and SDS for DBP and DBP absolute values. In the subgroup with non-ADPKD, we observed only a negative correlation between serum IL-6 concentration and SBP values and SDS for SBP.

In the subgroup of children with single cysts, we observed a significant negative correlation between IL-6 serum concentration and SBP $(\mathrm{r}=-0.404, \mathrm{p}<0.05)$, MAP $(\mathrm{r}=-0.368, \mathrm{p}<0.05)$, and SDS for SBP and SDS for DBP $(\mathrm{r}=-0.633, \mathrm{p}<0.0001, \mathrm{r}=-0.381, \mathrm{p}<0.05$, respectively). Also, in children with single cysts, we showed a negative correlation between urinary IL- 6 excretion and SDS for SBP and SDS for DBP $(r=-0.528, p<0.01, r=-0.523$, $\mathrm{p}<0.01$ ), and a positive correlation between IL- 6 excretion in the urine and eGFR $(\mathrm{r}=0.451, \mathrm{p}<0.05)$. Similar correlations were observed by analyzing the correlation between IL-6 and BMI (data not shown). However, we observed a significant positive correlation between IL-6/creatinine ratio and the age of the examined children $(\mathrm{r}=0.388, \mathrm{p}<0.05)$, height $(\mathrm{r}=0.391, \mathrm{p}<0.05)$ and body weight $(\mathrm{r}=0.387$, $\mathrm{p}<0.05$ ). In a subgroup with multiple cysts, we observed a significant negative correlation between L-FABP/BMI ratio and SDS for SBP $(r=-0.769$, $p<0.01)$. However, we did not observe similar correlations in the subgroup of children with single cysts. In the subgroup of children with multiple cysts, we observed a negative correlation between serum IL-6 concentration and MAP $(r=-0.642, \mathrm{p}<0.05)$. We also recorded a significant negative correlation between IL- 6 and BMI and SBP $(r=-0.873, p<0.01)$, MAP $(\mathrm{r}=-0.758, \mathrm{p}<0.05)$, and serum creatinine $(\mathrm{r}=-0.708$, $\mathrm{p}<0.05)$.

\section{Discussion}

Numerous clinical studies have confirmed the increased urinary excretion of L-FABP in kidney diseases in both children and adults. Many studies indicate the usefulness of the L-FABP assay as a biomarker for kidney disease, and L-FABP has also been shown to be able to relieve the occurrence of kidney damage. ${ }^{19,22,32}$ Oxidative stress and damage to the proximal renal tubules due to ischemia lead to increased urinary excretion of L-FABP, as shown by Małyszko et al. ${ }^{21}$ This was also confirmed by a metaanalysis carried out by Susantitaphong et al., which concluded that L-FABP provides adequate data to diagnose $\mathrm{AKI}$ and predict the necessity of renal replacement therapy and acute mortality. ${ }^{23}$

Khatir et al. evaluated the concentration of L-FABP in the group of adult patients with CKD stage 3-4, from which, however, patients with polycystic kidney disease were excluded. These authors showed that elevated L-FABP 
concentration in the urine correlates with the loss of renal function only in the absence of significant albuminuria. ${ }^{33}$

Matsui et al. followed 244 adult CKD patients for 3 years and confirmed that elevated urinary L-FABP concentration was associated with progression to ESRD and the incidence of severe cardiovascular events in these patients. ${ }^{34}$ In literature, no one before conducted research on the evaluation of L-FABP in a selected group of children with cystic kidney disease, nor did anyone make comparisons between groups of children with single and multiple renal cysts.

In our study, we showed a higher L-FABP concentration both in serum and in urine in children with cystic kidney disease, regardless of the underlying cysts etiology, which may indicate early damage of the proximal tubules even before the occurrence of renal impairment. McMahon et al. reviewed the usefulness of biomarkers in the diagnosis of kidney disease and indicated that increased urinary L-FABP excretion in patients with CKD correlated with the severity of proteinuria. ${ }^{22}$ When analyzing the correlation of serum and urine L-FABP concentrations by subgroup division, we showed a positive correlation between serum L-FABP concentration and serum creatinine and uric acid concentration in ADPKD children, which may indicate that L-FABP may be an early marker of CKD development.

Ichikawa et al. performed a study on experimental animals of the $R A S$-activated mouse model to evaluate the renoprotective effect of renal hL-FABP (human L-FABP). This study suggested that the increased expression of renal hL-FABP, known an antioxidant, together with the suppression of angiotensin II type 1 receptor appearance, blocked the production of pro-inflammatory cytokines and diminished the tubulointerstitial damage. ${ }^{35}$ In our previous work in the same group of children with renal cysts, we also demonstrated the activation of intrarenal RAAS. ${ }^{36}$ Ichikawa et al. concluded that agents that amplify the expression of renal L-FABP in the proximal tubules might be useful as therapeutic agents in future. ${ }^{37}$ In our study, a group of children with cystic kidney disease showed a significant negative correlation between serum L-FABP concentration and SDS for DBP. The above results may indicate the beneficial effect of L-FABP and the contribution of this antioxidant in inhibiting the development of hypertension in children with renal cystic changes. The pilot studies conducted by us also indicate the need for further research in a larger group of children with kidney cysts.

Many clinical trials in adults and children have confirmed the association of elevated IL- 6 levels with kidney disease, especially CKD progression. It is believed that the cause of this phenomenon is chronic inflammation in the kidney parenchyma, which is a common feature, characteristic for kidney damage due to various reasons. Determination of serum IL- 6 concentration may be useful in predicting the risk of end-stage renal disease. ${ }^{38}$ Nakamura et al., similarly to our results, found elevated
IL- 6 concentration in ADPKD adults, where the mean age of the study group was 57 years. In addition, these authors confirmed that IL- 6 levels decreased as a result of the renoprotective treatment with angiotensin converting enzyme inhibitor and/or angiotensin receptor blockade. ${ }^{39}$ In our study, we found in children with cystic renal changes significantly higher IL- 6 concentration in serum and urine, both in subgroups with ADPKD and non-ADPKD as well as with the division due to the number of cysts and gender, in comparison with healthy children, with no difference between individual subgroups. In addition, we have demonstrated a significant positive correlation between urinary IL- 6 concentration and eGFR, which indicates IL- 6 contribution in the deterioration of renal function. Menon et al. also showed increased levels of IL-6 in the serum of adolescents and adult patients with ADPKD. In this study, they divided the group of patients into 3 subgroups: ADPKD with normal BP and normal eGFR, ADPKD with hypertension but with normal eGFR and ADPKD with hypertension and reduced eGFR. The highest IL- 6 concentrations occurred in the subgroup with ADPKD with hypertension and depressed eGFR. ${ }^{40}$ In contrast, Soleimani et al. showed higher levels of L-FABP in urine in patients with ADPKD, but not in serum, compared to the healthy group, which would suggest only the local presence of inflammation in the renal parenchyma. ${ }^{41} \mathrm{Ma}$ et al. confirmed the association of 572 C > GG IL-6 polymorphism with the development of hypertension in the Asian population. ${ }^{28}$ However, in our study, we showed a significant negative correlation between the serum IL- 6 concentration and absolute values and SDS for SBP and DBP, and the value of MAP. There was also a significant negative correlation between urinary IL-6 concentration and SDS for SBP and DBP. Perhaps this is due to the other polymorphisms of the IL- 6 gene in the Polish population. Also, the mechanism of activation via binding of IL- 6 to its membrane-bound receptor IL-6R, which is named classic signaling (anti-inflammatory action) or binding via the trans-signaling with pro-inflammatory features, could play a role. ${ }^{17}$ These results indicate the need for further studies on a larger group of children with renal cysts to more accurately assess the role of this cytokine in the course of cystic changes in children and its contribution to the pathogenesis of hypertension.

In summary, we can conclude that higher concentrations of L-FABP and IL- 6 in both serum and urine in children with various types of kidney cysts indicate the development of chronic inflammatory processes and damage to the renal parenchyma even before the occurrence of other organ damage and hypertension. The L-FABP concentration seems to be a good biomarker for an increased risk of hypertension and kidney damage. A negative correlation of serum IL- 6 concentration with BP values requires further studies on a larger number of patients with renal cysts, with the determination of the type of IL- 6 gene polymorphism. Both L-FABP and IL- 6 appear to be useful biomarkers of CKD. 


\section{ORCID iDs}

Krzysztof Plesiński (10) https://orcid.org/0000-0002-0783-5620 Piotr Adamczyk (1) https://orcid.org/0000-0001-9557-221X Elżbieta Świętochowska (1) https://orcid.org/0000-0001-5787-7880 Aurelia Morawiec-Knysak (1) https://orcid.org/0000-0003-4914-6513 Aleksandra Gliwińska (10) https://orcid.org/0000-0002-4473-6840 Wojciech Korlacki (1) https://orcid.org/0000-0002-2632-3567 Maria Szczepańska (1) https://orcid.org/0000-0002-6772-1983

\section{References}

1. Osathanondh V, Potter EL. Pathogenesis of polycystic kidneys: Survey of results of microdissection. Arch Pathol. 1964;77:510-512.

2. Kim B, King BF, Vrtiska TJ, Irazabal MV, Torres VE, Harris PC. Inherited renal cystic diseases. Abdom Radiol (NY). 2016;41(6):1035-1051.

3. Audrezet MP, Corbiere C, Lebbah S, et al. Comprehensive PKD1 and PKD2 mutation analysis in prenatal autosomal dominant polycystic kidney disease. J Am Soc Nephrol. 2016;27(3):722-729.

4. Norman J. Fibrosis and progression of autosomal dominant polycystic kidney disease (ADPKD). Biochim Biophys Acta. 2011;1812(10): 1327-1336.

5. Nowak KL, Chonchol M, You Z, Gupta M, Gitomer B. Affected parent sex and severity of autosomal dominant polycystic kidney disease: A retrospective cohort study. Clin Nephrol. 2018;89(3):196-204.

6. Ravine D, Gibson RN, Donlan J, Sheffield LJ. An ultrasound renal cyst prevalence survey: Specificity data for inherited renal cystic diseases. Am J Kidney Dis. 1993;22(6):803-807.

7. Turco D, Severi S, Mignani R, Aiello V, Magistroni R, Corsi C. Reliability of total renal volume computation in polycystic kidney disease from magnetic resonance imaging. Acad Radiol. 2015;22(11):1376-1384.

8. Ravine D, Gibson RN, Walker RG, Sheffield LJ, Kincaid-Smith P, Danks DM. Evaluation of ultrasonographic diagnostics criteria for autosomal dominant polycystic kidney disease 1. Lancet. 1994;343(8903): 824-827.

9. Müller RU, Benzing T. Cystic kidney diseases from the adult nephrologist's point of view. Front Pediatr. 2018;6:1-8.

10. Simms RJ. Autosomal dominant polycystic kidney disease. BMJ. 2016; 352:1-10.

11. Pinto CS, Raman A, Reif GA, et al. Phosphodiesterase isoform regulation of cell proliferation and fluid secretion in autosomal dominant polycystic kidney disease. J Am Soc Nephrol. 2016;27(4):1124-1134.

12. Niemczyk M, Pilecki T, Gradzik M, Bujko M, Niemczyk S, Pączek L. Blood pressure and intracranial aneurysms in autosomal dominant polycystic kidney disease. Kidney Blood Press Res. 2014;39(6):630-635.

13. Dembowska M, Nieszporek T, Więcek A.Zwyrodnienie wielotorbielowate nerek jako przyczyna nadciśnienia tętniczego. Terapia. 2011; 19(7-8):14-18.

14. Schwartz GJ, Munoz A, Schneider MF, et al. New equations to estimate GFR in children with CKD. J Am Soc Nephrol. 2009;20(3):629-637.

15. Cornec-Le Gall E, Audrezet MP, Rousseau A, et al. The PROPKD Score: A new algorithm to predict renal survival in autosomal dominant polycystic kidney disease. J Am Soc Nephrol. 2016;27(3):942-951.

16. Marlais M, Cuthell O, Langan D, Dudley J, Sinha MD, Winyard PJ. Hypertension in autosomal dominant polycystic kidney disease: A metaanalysis. Arch Dis Child. 2016;101(12):1142-1147.

17. Hogan MC, Abebe K, Torres VE, et al. Liver involvement in early autosomal-dominant polycystic kidney disease. Clin Gastroenterol Hepatol. 2015;13(1):155-164.

18. Glatz JF, Van der Vusse GJ. Cellular fatty acid-binding proteins: Their function and physiological significance. Prog Lipid Res. 1996;35(3): $243-282$.

19. Xu Y, Xie Y, Shao X, Ni Z, Mou S. L-FABP: A novel biomarker of kidney disease. Clin Chim Acta. 2015;445:85-90.

20. Smathers RL, Petersen DR. The human fatty acid-binding protein family: Divergences and functions. Hum Genom. 2011;5(3):170-191.
21. Małyszko J, Bachorzewska-Gajewska H, Dobrzycki S. Biomarkers of contrast-induced nephropathy: Which ones and what is their clinical relevance? Interv Cardiol Clin. 2014;3(3):379-391.

22. McMahon GM, Waikar SS. Biomarkers in nephrology: Core Curriculum 2013. Am J Kidney Dis. 2013;62(1):165-178.

23. Susantitaphong P, Siribamrungwong M, Doi K, Noiri E, Terrin N, Jaber BL. Performance of urinary liver-type fatty acid-binding protein in acute kidney injury: A meta-analysis. Am J Kidney Dis. 2013;61(3): 430-439.

24. Schaper F, Rose-John S. Interleukin 6: Biology, signaling and strategies of blockade. Cytokine Growth Factor Rev. 2015;26(5):475-487.

25. Wolf J, Rose-John S, Garbers C. Interleukin- 6 and its receptors: A highly regulated and dynamic system. Cytokine. 2014;70(1):11-20.

26. Tanaka T, Kishimoto T. The biology and medical implications of interleukin 6. Cancer Immunol Res. 2014;2(4):288-294.

27. Chiesa C, Pacifico L, Natale F, Hofer N, Osborn JF, Resch B. Fetal and early neonatal interleukin 6 response. Cytokine. 2015;76(1):1-12.

28. $\mathrm{Ma} \mathrm{H}$, Sun $\mathrm{G}$, Wang W, et al. Association between interleukin-6 -572 C> G and -174- G>C polymorphisms and hypertension: A meta-analysis of case-control studies. Medicine. 2016;95(2):e2416. doi: 10.1097/ MD. 0000000000002416

29. Litwin M. Nadciśnienie tętnicze pierwotne u dzieci i młodzieży - patofizjologia. [In:]. Litwin M, Januszewicz A, Prejbisz A. ed. Nadciśnienie tętnicze u młodzieży i młodych dorosłych. Zapobieganie, diagnostyka i leczenie. Kraków, Poland: Medycyna Praktyczna; 2011:289-315.

30. Kułaga Z, Litwin M, Grajda A, Gurzkowska B, Napieralska E, Kułaga K. Rozkłady wartości ciśnienia krwi w populacji referencyjnej dzieci i młodzieży w wieku szkolnym. Standardy medyczne. Pediatria. 2010; 7:100-111.

31. Kułaga Z, Rożdżyńska A, Palczewska I, Grajda A, Gurzkowska B, Napieralska E. Siatki centylowe wysokości, masy ciała i wskaźnika masy ciała dzieci i młodzieży w Polsce - wyniki badania OLAF. Standardy medyczne. Pediatria. 2010;7:690-700.

32. Sato R, Suzuki $Y$, Takahashi G, Kojika M, Inoue Y, Endo S. A newly developed kit for the measurement of urinary liver-type fatty acidbinding protein as a biomarker for acute kidney injury in patients with critical care. J Infect Chemother. 2015;21(3):165-169.

33. Khatir DS, Bendtsen MD, Birn $\mathrm{H}$, et al. Urine liver fatty acid binding protein and chronic kidney disease progression. Scand J Clin Lab Invest. 2017:77(7):549-554.

34. Matsui K, Kamijo-Ikemori A, Imai N, et al. Clinical significance of urinary liver-type fatty acid-binding protein as a predictor of ESRD and CVD in patients with CKD. Clin Exp Nephrol. 2016;20(2):195-203.

35. Ichikawa D, Kamijo-lkemori A, Sugaya T, et al. Renoprotective effect of renal liver-type fatty acid binding protein and angiotensin II type 1a receptor loss in renal injury caused by RAS activation. Am J Physiol Renal Physiol. 2014;306(6):F655-F663.

36. Plesiński K, Adamczyk P, Świętochowska E, et al. Angiotensinogen and interleukin 18 in serum and urine of children with kidney cysts. $J$ Renin Angiotensin Aldosterone Syst. 2019;20(3):1470320319862662. doi:10.1177/1470320319862662

37. Ichikawa D, Kamijo-Ikemori A, Sugaya T, et al. Renal liver-type fatty acid binding protein attenuates angiotensin II-induced renal injury. Hypertension. 2012;60(4):973-980.

38. Jones SA, Fraser DJ, Fielding CA, Jones GW. Interleukin 6 in renal disease and therapy. Nephrol Dial Transplant. 2015;30(4):564-574.

39. Nakamura T, Sato E, Fujiwara N, et al. Changes in urinary albumin excretion, inflammatory and oxidative stress markers in ADPKD patients with hypertension. Am J Med Sci. 2012;343(1):46-51.

40. Menon V, Rudym D, Chandra P, Miskulin D, Perrone R, Sarnak M. Inflammation, oxidative stress, and insulin resistance in polycystic kidney disease. Clin J Am Soc Nephrol. 2011;6(1):7-13.

41. Soleimani A, Adabavazeh R, Nikoueinejad H, Sharif MR, Faraji S, Shahreza BO. T helper 17 lymphocyte pathway in the diagnosis of autosomal dominant polycystic kidney disease. Iran J Kidney Dis. 2015;9(2):105-112. 